lja se nadati prijevodu knjige na bosanski jezik, što bi bilo temelj autoričinih daljnjih istraživanja, možda i u okružju bosanskohercegovačkog društva, o primjerice iskustvima izbjeglica povratnika i na- činima prevladavanja traume, ili transnacionalnim praksama bosanskih izbjeglica koje ih povezuju s prostorima koje su napustili i kamo se (ne) vraćaju.

\section{Drago Župarić-Iljić}

Institut za migracije i narodnosti, Zagreb
DOI: 10.11567/met.28.3.5 Jasna Čapo i Valentina Gulin Zrnić (ur.)

\section{Mjesto, nemjesto. Interdisciplinarna promišljanja prostora i kulture}

\begin{abstract}
Zagreb - Ljubljana: Institut za etnologiju i folkloristiku - Inštitut za antropološke in prostorske študije - Znanstvenoraziskovalni center Slovenske akademije znanosti in umetnosti, 2011, 441 str.
\end{abstract}

Zbornik objedinjuje radove izložene na konferenciji »Od mjesta do nemjesta: interdisciplinarna promišljanja prostora i kulture« koja se 24. i 25. rujna 2009. održala u Institutu za etnologiju i folkloristiku u Zagrebu. Uz opširno uvodno poglavlje urednica zbornik sadržava dvadeset radova na hrvatskome i engleskome podijeljenih na sedam tematskih cjelina. Jasna Čapo i Valentina Gulin Zrnić u uvodnom poglavlju »Oprostornjavanje antropološkog diskursa. Od metodološkog problema do epistemološkog zaokreta« nastoje obuhvatiti »kretanja, smjerove, rubove, granice i graničnosti, mozaike i tokove u odnosu kulture i prostora unutar kulturne antropologije i srodnih disciplina i pristupa" (str. 13). Autorice daju pregled relevantnih koncepata i predstavljaju radove u zborniku smještajući ih u okvir pojedinih pristupa prostoru, mjestu i kulturi. Odnos kulture i prostora tematizira se kroz nekoliko dimenzija (od klasičnih poimanja prosto- ra kao kontejnera kulture do suvremenih koncepata koji naglašavaju njihov procesni i relacijski karakter), a rad ispunjava očekivanja autorica, tj. uistinu je »korisni putokaz u kretanju ovim specifičnim akademskim prostorom « (str. 13).

Prvi dio zbornika Disciplinarne prizme, znanstvene lokacije i nova značenja sadržava četiri rada. »Prostor i mjesto u hrvatskoj etnologiji/kulturnoj antropologiji« Valentine Gulin Zrnić pregled je relevantnih etnoloških i etnografskih radova kroz nekoliko tematskih cjelina, od klasičnih razmatranja izomorfnosti kulture i fizičkog prostora u Radićevim i Gavazzijevim radovima preko konceptualnih pomaka u pristupu prostoru u istraživanjima arhitekture, graditeljstva i stanovanja $\mathrm{s}$ jedne i primjerice turizma i ekologije $\mathrm{s}$ druge strane, do radova koji tematiziraju »transnacionalne društvene prostore«, virtualne prostore i druge koncepte koji ne pretpostavljaju istovjetnost zajednica i lokalitetâ. U svome radu Laura Šakaja razmatra »Mjesto u diskursu humane geografije« od njegova lokacijskog aspekta, preko fenomenološke koncepcije »osjećaja mjesta«, koncepta »trećeg prostora i odnosa mjesta s prostorom i teritorijem, obuhvaćajući utjecajne koncepcije i njihovu kritiku. U ovome dijelu nalaze se još i radovi Sarah Czerny i Melanije Belaj, koji su, poput priloga koji slijede u zborniku, etnografske studije, u ovom sluča- 
ju vlasnika naslijeđenih obiteljskih kuća i njihovih susjeda kroz prizmu geografskoga i prostornog pozicioniranja subjekata i antropologa (Czerny), odnosno obiteljske proizvodnje alkoholnih pića u kontekstu transformacije značenja pojma »terroir« od geografskih osobina mjesta porijekla vina preko tradicijskog nasljeđa različitih lokalnih proizvoda do turističkog terroira (Belaj).

Dio Povijest i pamćenje sastoji se od dva rada. »Reconstructing the Past of Himarë/Himara, Southern Albania« Nataše Gregorič Bon studija je suprotstavljenih rekonstrukcija prošlosti južnoalbanske regije u iskazima pripadnika albanske i grčke etničke skupine, uključujući interpretacije lokalnih stanovnika i znanstvenika. Bojan Mucko u radu »Projekt Bilježenje grada/bilježenje vremena kao relacijski okvir društvenoga pamćenja« uz pomoć Norinih i Assmanovih koncepcija analizira razine kolektivne memorije koje se ostvaruju kroz komunikacijske i interakcijske segmente projekta usredotočenoga na subverzivne umjetničke akcije, politička okupljanja i proteste u Zagrebu od 1900. do danas.

Treća tematska cjelina Prijeporni prostori obuhvaća tri rada. Katja Jerman iz perspektive antropološke interpretacije mjesta (Augé) istražuje odnose pograničnih gradova Nove Gorice i Gorizije, uključujući individualne, grupne i institucionalne aktere, s posebnim naglaskom na prijeporni prostor zajedničkoga novoizgrađenog trga. Sanja Puljar D’Alessio u radu »Projekcija simboličkih prostora u sporna mjesta. Mostar « analizira nastanak i manifestiranje »simboličkog bojnog polja u nastavku rata drugim sredstvima« (str. 229) u prostoru toga podijeljenoga grada. U ovoj je tematskoj cjelini i rad Marijane Belaj, koja razmatra »Međugorje kao proces «, tj. kreiranje mjesta iskustvom hodočašćenja.
Prostori i moć naslov je četvrtog dijela zbornika, u kojemu Sanja Đurin uz pomoć Foucaultove koncepcije disciplinske moći istražuje iskustva boravka u lepoglavskoj kaznionici u radu »Lepoglavski Panoptikon - prostor, moć, identitet«. Ian Woodcock i Jan Smitheram u svome radu analiziraju dvije lokacije u multikulturnome Melbourneu iz perspektive prostorne medijacije raznovrsnih oblika moći kroz stvaranje i nastajanje identiteta mjesta - od moći ideologije bijele rase »odozgo« do moći korisnikâ gradskog prostora »odozdo《.

Peti dio Javni prostori sadržava dva sociološka rada. Anđelina Svirčić Gotovac razmatra »Aspekte ugroženosti javnih prostora« od nedovoljnog sudjelovanja građana u njihovu oblikovanju, preko klasne segregiranosti u javnim gradskim prostorima do širenja trgovačkih centara i drugih nemjesta kao nedovoljno javnih prostora. Na tu temu nadovezuje se rad Jelene Zlatar, koja upotrebljavajući Augéov koncept nemjesta analizira utjecaj zagrebačkih trgovačkih centara kao pseudojavnih prostora na smanjenje klasičnih javnih prostora.

Dio Dom, domovina, svijet: umještanje izmještenog obuhvaća tri priloga. Jasna Čapo u radu »Dvadeset godina poslije. Stvaranje doma u kontekstu prisilno preseljenih osoba« propituje odnos mjesta, identifikacije s mjestom i stvaranja osjećaja pripadanja i doma srijemskih doseljenika u Hrvatskoj. Autorica upućuje i na potrebu revidiranja tradicionalne esencijalističke i teritorijalizirajuće konceptualizacije »doma« u korist fluidnije, plurilokalne koncepcije. U prilogu »Dug povratak domu. Migrantsko iskustvo domova, odlazaka i povrataka« Petar Bagarić na primjeru životnog iskustva sugovornika razmatra doživljaj višestrukih migracija i različita poimanja doma, razmatraju- 
ći neadekvatnost klasičnih koncepata »odlaska« $\mathrm{i}$ »povratka«. Rad »Gdje grenlandski Turci prodaju led. Pokušaj lociranja transl(ok)acija jednog dislociranog opusa« studija je dijela skladateljskog opusa Darka Rundeka nakon dolaska u Pariz, koji autorica Mojca Piškor interpretira kroz postkolonijalnu kritiku klasičnoga koncepta dijaspore.

Sedma i zadnja cjelina Fizičko $u$ virtualnom: imaginacija i lokacija sadržava četiri rada. Iva Pleše razmatra internetski posredovanu komunikaciju iz »prostorne perspektive « naglašavajući sličnosti i razlike web-forumâ i fizičkih lokaliteta, uključujući razmatranje web-forumâ kao etnografskih terena. Ana-Marija Vukušić na primjeru »lokalnog « web-foruma koji služi kao »mjesto okupljanja« osoba (porijeklom) iz Imotske krajine istražuje prožimanje virtualnoga i stvarnog prostora. Tu su još i rad Sonje Leboš, koja istražuje »virtualni svijet« Second Life u kontekstu konstrukcije identiteta, uključujući i raspravu o interakciji virtualnih i akademskih zajednica, te prilog Ratka Cvet- nića i Mladena Klemenčića, koji predstavljaju Virtualni zavičajni muzej novozagrebačkog naselja Trnsko naglašavajući njegov doprinos jačanju kvartovskoga identiteta stanovnika.

Posebna je vrijednost zbornika prvih nekoliko priloga, koji sistematiziraju različite pristupe i koncepte prostora u međunarodnoj i domaćoj društveno-humanističkoj znanstvenoj produkciji (Čapo i Gulin Zrnić, Gulin Zrnić, Šakaja), a za čitatelje ovog časopisa naročito će biti interesantni radovi koji tematiziraju migrantska iskustva (npr. Bagarić, Čapo), kao i studije koje uključuju različite aspekte etničkih odnosa povezujući ih s raznovrsnim koncepcijama prostora i mjesta (npr. Gregorič Bon, Jerman, Puljar D'Alessio). Iako je, prema riječima urednica, »zbornik primarno pripremljen propitivanjima proizašlima iz antropoloških istraživanja i senzibiliteta te znanosti« (str. 12), on će biti korisno i zanimljivo štivo širemu krugu čitatelja različitih disciplinarnih provenijencija humanističkih i društvenih znanosti.

\section{Simona Kuti}

Institut za migracije i narodnosti, Zagreb 